\title{
Magneto-seismic interpretation of subsurface volcanism in the Gaeta Gulf (Italy, Tyrrhenian Sea)
}

\author{
Giovanni de Alteriis $\left({ }^{1}\right)\left({ }^{2}\right)$, Maurizio Fedi $\left({ }^{3}\right)$, Salvatore Passaro $\left({ }^{1}\right)$ and Agata Siniscalchi $\left({ }^{4}\right)$ \\ (') Istituto Ambiente Marino Costiero (IAMC), CNR, Napoli, Italy \\ $\left({ }^{2}\right)$ GeoLab srl, Marine Surveys, Pozzuoli (NA), Italy \\ (3) Dipartimento di Scienze della Terra, Università degli Studi di Napoli «Federico II», Napoli, Italy \\ $\left({ }^{4}\right)$ Dipartimento di Geologia e Geofisica, Università degli Studi di Bari, Italy
}

\begin{abstract}
The occurrence of a former subaerial volcanic edifice off the Volturno River (Tyrrhenian Sea, Gulf of Gaeta) in the $41^{\circ} \mathrm{N}$ parallel is suggested by joint interpretation of multichannel seismic lines and ship-borne magnetic data. In the Campanian region igneous (volcanic) rocks are very close to the carbonate Mesozoic basement and seismics cannot always discriminate between them. A joint seismic-magnetic analysis was very effective in assessing the lithological nature of the bodies evidenced by both geophysical methods. Distortion analysis showed that the main magnetic source in the area is characterised by a not normal-polarity direction of the magnetization, similar to other Pleistocene volcanoes in the Tyrrhenian region. Hence we argued that the overall magmatic emplacement for this source occurred during a reverse-polarity chron, very likely the $0.78-1.78 \mathrm{Ma}$ time span. This magnetically-derived time constraint is in agreement with seismic stratigraphy that shows that the entire volcano is sealed by the Volturno River prograding delta from Middle Pleistocene to Present in age. Our interpreted volcano belongs to a set of inferred onshore and offshore volcanic edifices all lying along the $41^{\circ} \mathrm{N}$ parallel.
\end{abstract}

Key words Gaeta Gulf $-41^{\circ} \mathrm{N}$ parallel - buried volcanism - inverted magnetic anomalies - reflection seismics

\section{Introduction}

Seismic and magnetic prospecting are among the most suitable methods for exploring volcanic areas and their integration may significantly improve detection of buried bodies. The internal structure of strato-volcanoes is generally not well seismically layered, whereas pyro-

Mailing address: Dr. Giovanni de Alteriis, GeoLab srl, Marine Surveys, Via Monteruscello 75, 80078 Pozzuoli (NA), Italy; e-mail: giovanni.dealteriis@geolab.it clastic sequences embedded in marine deposits or buried pyroclastic tuff edifices may, in a few instances, be distinguishable from seismics. On the other hand, the total magnetisation of these pyroclastic edifices is generally lower than that of composite volcanoes or that of igneous intrusions, mostly due to the greater susceptibility of compact igneous rocks compared to pyroclastic rocks. Advanced boundary analysis techniques of the magnetic field, e.g., EHD Enhanced Horizontal Derivative (Fedi and Florio, 2001) and AS Analytic Signal (Roest et al., 1992; Hsu et al., 1996) can provide useful constraints to the extent of buried igneous bodies. Furthermore, distortion analysis (Fedi et al., 1994; Naidu and Matthew, 1998) may help in searching for the paleo-declination and inclination at the time of emplacement of the igneous mass, thus providing an age range for the source. 
Magnetic boundary analysis may be matched with constraints imposed by seismic data and their interpretation (e.g., seismic stratigraphy).

In this paper we used such techniques over an area of the Latium-Campania offshore (Tyrrhenian Sea) located across the $41^{\circ} \mathrm{N}$ parallel. This area was relatively well known through seismics (Bartole et al., 1984; Aiello et al., 2000; Bruno et al., 2000) but poorly constrained by magnetic data. The close coexistence of carbonates and volcanic edifices, characterised by similar seismic velocity values, makes this site particularly suitable for a joint magneto-seismic interpretation. The dataset consists of shipborne magnetic data collected during two oceanographic cruises in 1992 and 1993 on board of R/V Urania (CNR, Italy) and a partially unpublished multichannel seismic grid (courtesy of Agip, Eni division, Milan-Italy).

\section{Geologic and geophysical setting}

The Campania-Latium offshore belongs to the Eastern Tyrrhenian Margin (ETM), characterised by lithospheric thinning and volcanism during most of the Plio-Quaternary as a consequence of the Tyrrhenian sea opening (Trincardi and Zitellini, 1987). It includes three Plio-Quaternary extensional basins corresponding to the Salerno, Napoli and Gaeta Gulfs and their coastal plains. In the Gaeta Gulf the continental shelf is the seaward extension of the Garigliano and Volturno coastal alluvial plains filled by PlioQuaternary clastic and volcanics. It narrows from NW to SE (from some $10 \mathrm{~km}$ to few kilometres north of Ischia Island). The estimated Pleistocene tectonic subsidence-rate is in the order of 1600 $\mathrm{m} / \mathrm{My}$ based on subsurface well stratigraphy (Ippolito et al., 1973; Brancaccio et al., 1991).

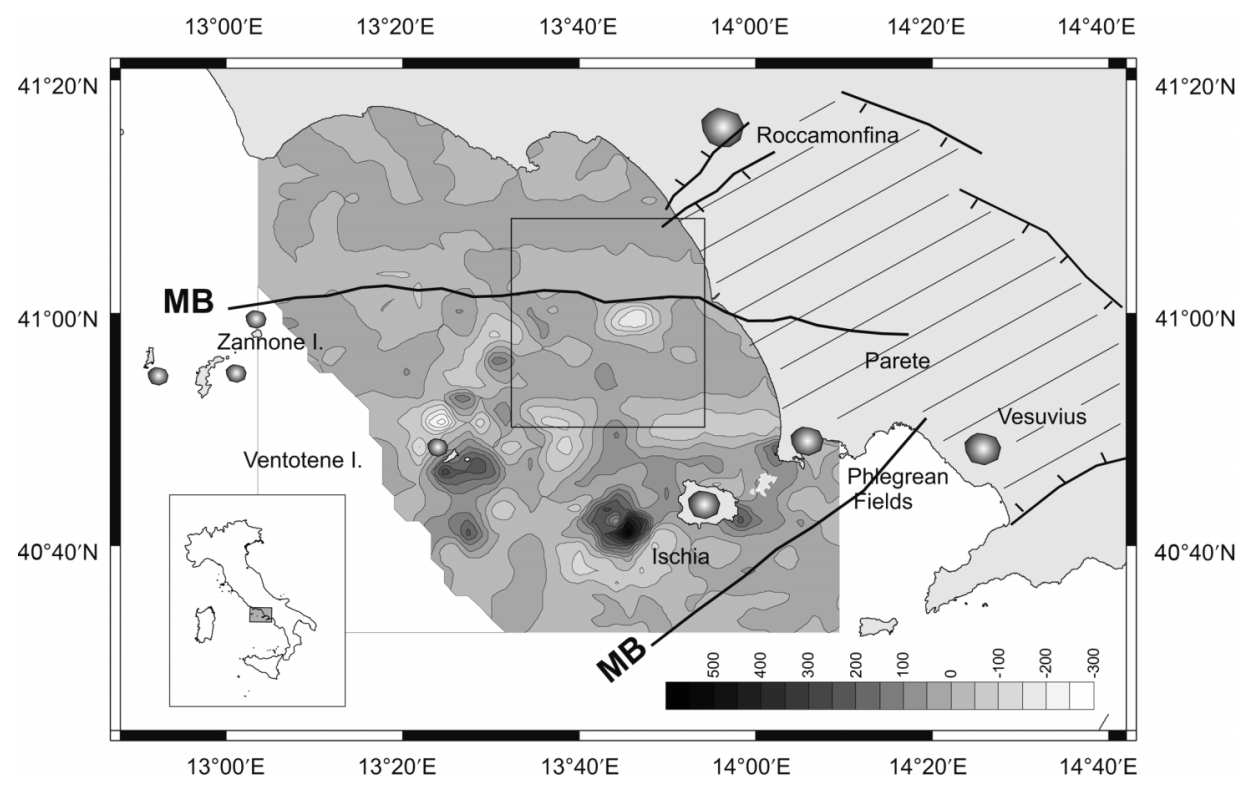

Fig. 1. Location of the surveyed area (outlined) in the frame of the Campania offshore along the Eastern Tyrrhenian margin at $41^{\circ} \mathrm{N}$. Filled, gray-scale contour represents the aeromagnetic anomaly field with scale bar in nT. Note the two sharp Magnetic Boundaries (MB) along the $41^{\circ} \mathrm{N}$ parallel and across the Bay of Naples defining a triangular region, where most volcanic activity has occurred during Plio-Quaternary. The two magnetic boundaries converge towards the area of the Parete subsurface volcano. The extension of the fault- bordered Campanian alluvial plain is outlined (oblique texture) as well as subaerial volcanic districts. 
The area is marked by a well evident regional magnetic lineament (fig. 1), occuring along the $41^{\circ} \mathrm{N}$ parallel, first recognised by Savelli and Wezel (1979) and Wezel (1985) that interpreted it as a strike-slip zone. Other authors interpreted this lineament as a transform fault (Selli, 1981) or as a transfer fault (Bruno et al., 2000). Unlike other magnetic/morphologic discontinuities (e.g., the NE-SW «Selli line» running across the entire Tyrrhenian Basin), the $41^{\circ} \mathrm{N}$ line does not show a clear morphologic signature, as recently confirmed by swath bathymetry (Marani and Gamberi, 2004). On the other hand, in the subsurface, a structural high about $80 \mathrm{~km}$ long, running from the Zannone Island to Volturno River was formerly recognised in the Gulf of Gaeta by Bartole et al. (1984) and named the «Zannone-Volturno overthrust».

Magmatism related to crustal extension along normal or partially strike-slip faults is represented in the region by widespread volcanic activity onshore and offshore. Major subaerial composite volcanoes or poligenic edifices (Roccamonfina, Phlegraean Fields and Somma-Vesuvius) lie in the Campanian alluvial plain in structural NESW and NW-SE conjugate structural systems with age ranging from $0.7 \mathrm{Ma}$ to Present. At sea early Pliocene-Pleistocene rhyolitic magmatism characterizes Ponza, Palmarola and Zannone islands. Ventotene and Ischia-Procida polygenic volcanoes have produced less differentiated magmas with ages ranging from $0.75 \mathrm{Ma}$ (Ventotene) to Present (Ischia) (Capaldi et al., 1985; De Rita et al., 1986).

Well and seismic data, acquired in the frame of oil and geothermal exploration (Mariani and Prato, 1988) indicate the presence, in the subsurface of the Campanian plain, of a Pleistocene sedimentary sequence consisting of deltaic, alluvial and marine deposits intercalated with piroclastic and lava sequences. The basin depocentre attains some $4000 \mathrm{~m}$ of thickness $(2500 \mathrm{~ms}$ in twt) near the Volturno River mouth. Sub-surface stratigraphy in the offshore is limited to the data of the «Mara1» well (total depth $2906 \mathrm{~m}$ from sea-floor), that is located north of the $41^{\circ} \mathrm{N}$ line and has not encountered volcanics but only deltaic, continental and marine Plio-Quaternary sequences overlying a meso-cenozoic thrusted basement (Aiello et al., 2000).

\section{Seismic and magnetic data-sets}

\subsection{Seismic dataset}

The seismic dataset includes 11 multichannel seismic profiles acquired in the course of two surveys characterised by the same energy source (Aquapulse $($ ) ) but different acquisition and processing parameters (fig. 2). The older seismic grid (24-channels, $1630 \mathrm{~m}$ long streamer, $4 \mathrm{~ms}$ sample rate, $68 \mathrm{~m}$ shot and group interval, $10-80 \mathrm{~Hz}, 1200 \%$ coverage) was acquired by Western Geophysical Company in 1968 on commitment of Italy's Minister of Industry in the frame of a regional survey over the entire Eastern Tyrrhenian continental shelf.

It includes, in the Gulf of Gaeta, 9 lines totalling $330 \mathrm{~km}$, that we interpreted in their originally processed version (basically pre-stack deconvolution and $1200 \%$ stack).

A more recent unpublished dataset acquired in 1980 by western and kindly provided by Agip offers higher resolution acquisition parameters (96 channel-2400 m long streamer, 25 $\mathrm{m}$ shot and group interval, $2 \mathrm{~ms}$ sample rate, $30-50 \mathrm{~Hz}$ band-pass frequency range, $4800 \%$ coverage (E80-31 and E80-40 profiles). Processing included: predictive deconvolution before stack, RMS gain correction to reduce signal amplitude before the velocity analysis, NMO correction, $4800 \%$ stacking and a timevariant filtering application.

\subsection{Magnetic dataset}

During the GMS92 and GMS93 cruises (October 1992 and October 1993, R/V Urania) about $940 \mathrm{~km}$ magnetic profiles were acquired (fig. 2) with a EG\&G G811 proton magnetometer that ensured a $0.5 \mathrm{nT}$ accuracy at an average sampling rate of $1 \mathrm{~s}$. The sensor was towed at a minimum distance of $250 \mathrm{~m}$ from ship, at depths ranging from 10 to $40 \mathrm{~m}$, depending on ship velocity and cable length. Sensor depth was continually monitored and recorded for subsequent default corrections. Cruising speed did not exceed 5 knots, GPS positioning ensured an accuracy in the order of 30-50 m. The magnetic data were recorded at an average spatial sampling rate of 


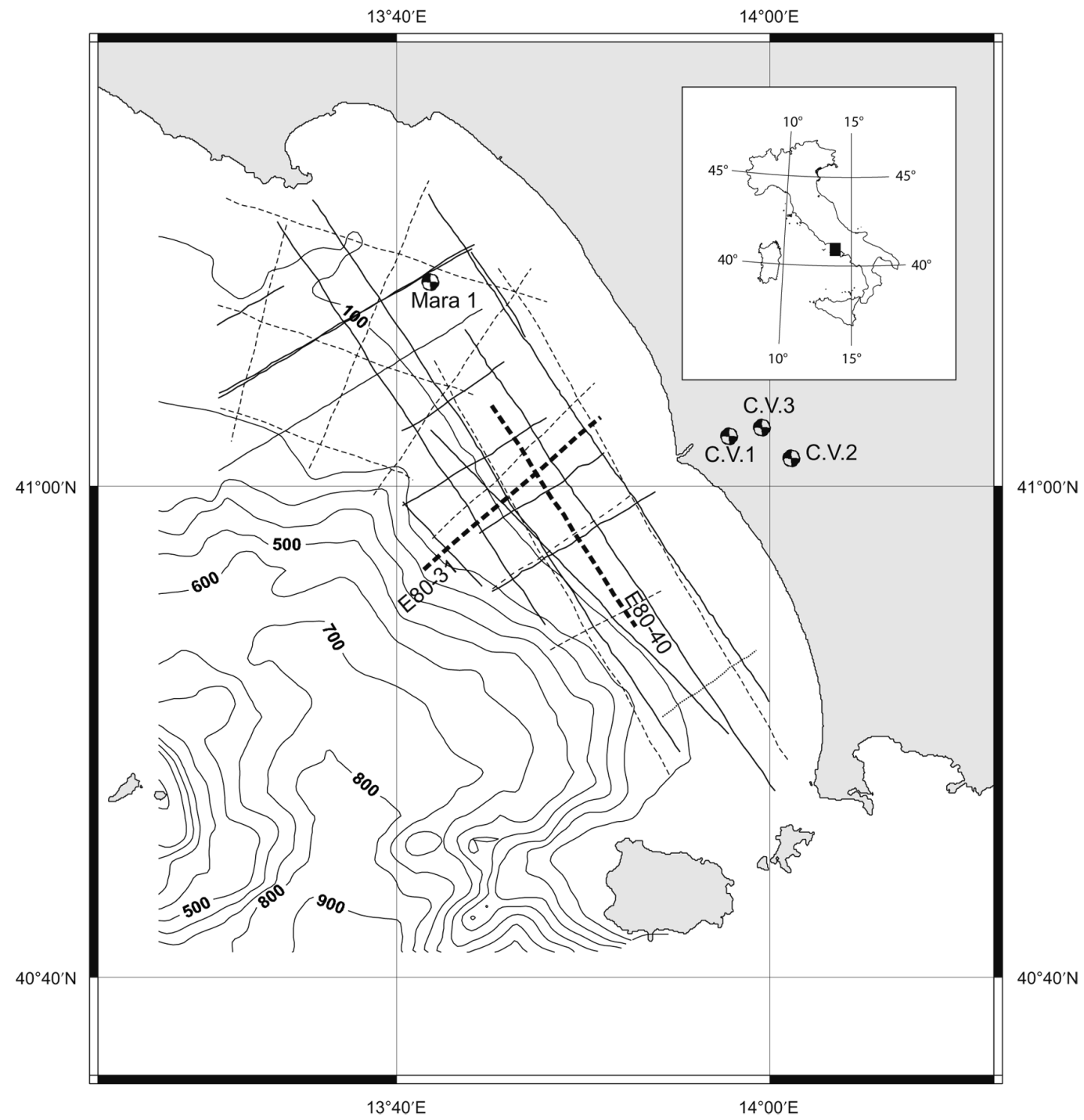

Fig. 2. Geophysical dataset used in this study. 1968 regional multichannel seismic grid (Aquapulse@ source): thin dashed lines; GMS92 and GMS93 magnetometric grids acquired during R/V Urania cruises in 1992 and 1993: thin continuous lines. E80-31 and E80-40 (bold dashed lines) are two multichannel seismic profiles provided by Agip company and shown in figs. 3 and 4. Location of Mara 1 and Castel Volturno (CV) wells drilled offshore and onshore by Agip is shown.

$140 \mathrm{~m}$ at times reduced to $70 \mathrm{~m}$ in areas characterised by intense lateral variations. Pre-processing first aimed at temporal and spatial (layback) corrections. The two sub-data sets acquired in
October 1992 and October 1993 were time reduced to the year 1995. Temporal corrections (including also the diurnal variations) were referred to the L'Aquila (Italy, $42^{\circ} \mathrm{N} ; 12^{\circ} \mathrm{E}$ ) Geo- 
magnetic Observatory. In any case, the field measurements were acquired during a relatively quiet magnetic period. After an accurate re-positioning of all wrong navigation fixes due to GPS «jumps», a correction was applied to take into account local deviations from rectilinear ship tracks. Layback correction due to offset between the towed sensor and the GPS antenna and levelling for sensor depth variations, in the order 10$20 \mathrm{~m}$, were applied. Cross-over errors at each node of the grid were then computed in order to evaluate data quality, their amplitude was always $<1 \%$ of the measured field value.

\section{Seismic data interpretation}

The key that has guided our seismo-stratigraphic interpretation is based on both 1969 and
1980 datasets (totalling $400 \mathrm{~km}$ of multichannel lines, figs. 3 and 4), including «pre and post-rift» sequences. Consequently the entire record has been divided into five seismic units (namely 1, 2, 3, 4 and 5) and 4 unconformities (namely A, B, $\mathrm{C}$ and $\mathrm{D})$. The pre-rift sequences, partly coinciding with basement rocks, consist of Mesozoic carbonates and Miocene flysch terrains (Units 1 and 2). While carbonates are characterised by a chaotic, high amplitude seismic facies, the more terrigenous Unit 2 shows a relatively coherent, high amplitude facies. The two units are separated by a tectonic or depositional discontinuity (Unconformity A). The overall pre-rift assemblage is truncated by B erosional unconformity. The B unconformity locally coincides with either the top of carbonates Unit 1 (e.g., A unconformity) or the top of Unit 2 (Miocene flysch) or the top of volcanic bodies (figs. 3 and 4). Its
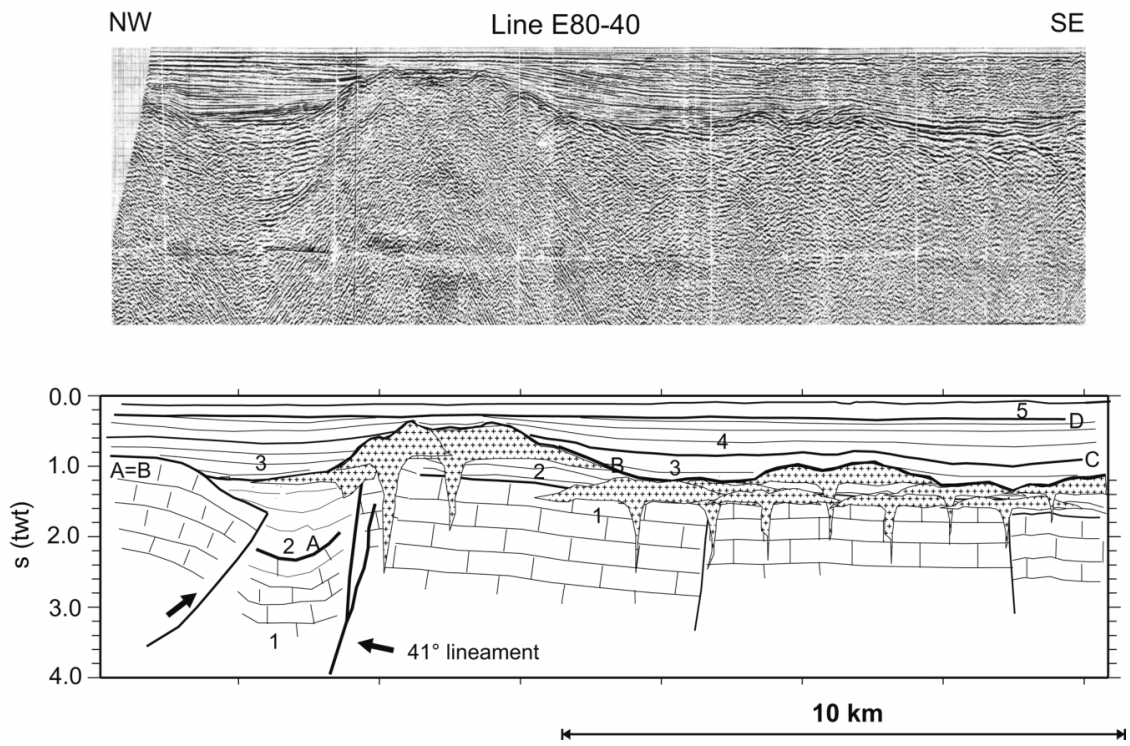

Fig. 3. E80-40 multichannel line and interpretation. Location in fig. 2. Legend: 1 - Mesozoic carbonates; 2 Miocene Flysch terrains; 3 - Early Pleistocene marine or transitional sediments; 4 - Middle Pleistocene deltaic and possibly marine and volcanoclastic sediments; 5 - Late Pleistocene-Holocene transitional, marine and volcanoclastic sediments. A - seismic erosional non depositional unconformity at the top of mesozoic carbonates. B - Time transgressive unconformity locally coinciding with the top of Unit 1 or Unit 2 or volcanic-igneous bodies. The $41^{\circ}$ tectonic lineament is here interpreted as strike-slip fault. Note the absence of subsurface volcanism north of this lineament. 

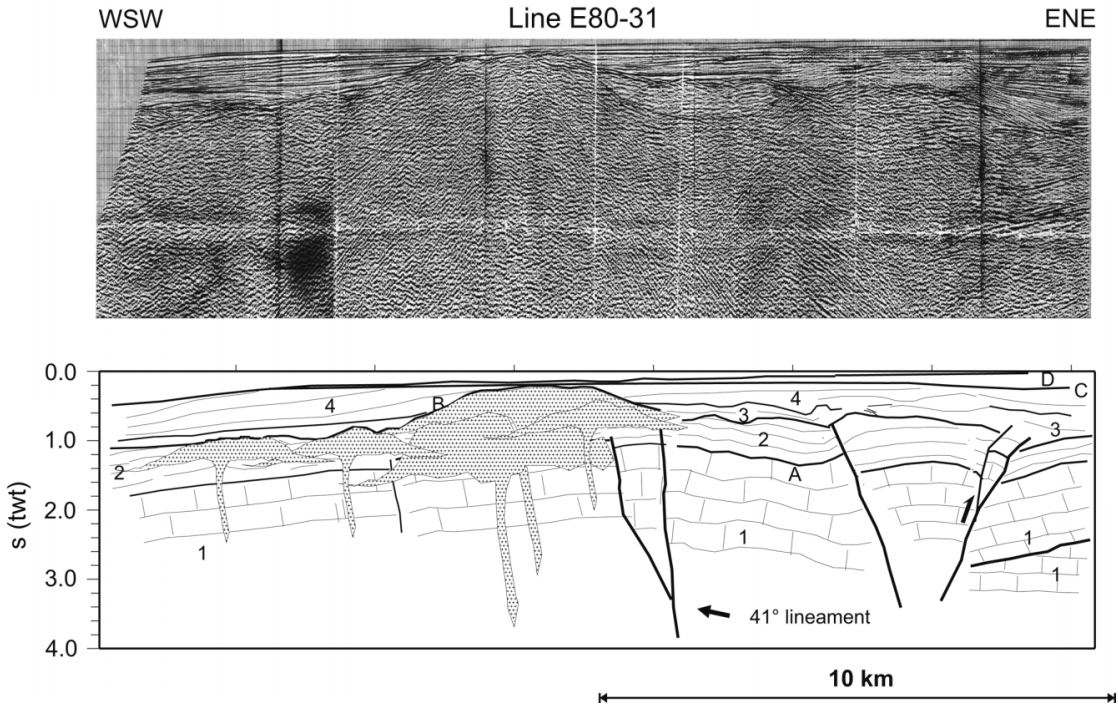

Fig. 4. E80-31 multichannel profile and interpretation. Location in fig. 2. Legenda as in fig. 3.

meaning is that of a time-transgressive subaerial unconformity that marks the onset of fast tectonic subsidence, the emplacement of typical postrift sequences (Units 3, 4 and 5), and the burial of pre-existing subaerial edifices. The base of the marine basin fill (Unit 3) is easily detectable on seismics given the very clear contrast between planar-parallel marine reflectors and more chaotic seismic facies that characterises Units1 and 2. Unit 3 is overlain by the $\mathrm{C}$ para-conformity marking the base of the Volturno River prograding wedge, i.e. Unit 4 , with the emplacement of deltaic and continental sequences. Unit 4 is on turn top lapped or eroded by the D unconformity subsequently overlain by transgressive Late Pleistocene (Unit 5) deposits. The age of Units 3, 4 and 5 can be tentatively assigned to the Middle-Late Pleistocene (about 0.7-0 Ma) based on indirect calibration with Castel Volturno1, 2, 3 wells onshore (fig. 2).

In order to image the seismic interface that might be identified with the top of a susceptive basement we picked the B unconformity in the time domain. Despite their different resolution and penetration, all profiles showed very clearly this surface. As already said B locally corresponds either to buried volcanic edifices or ig- neous, non volcanic bodies (laccolithes, mega dykes, etc.) or to carbonatic-flyschoid rocks.

Time to depth conversion of B reflector was successively applied on the basis on 18 RMS and interval velocity profiles spaced $1 \mathrm{~km}$ along the E80-40 and E80-31 seismic sections. The resulting depth map (fig. 5) shows an elongated ridge consisting of various crestal highs faulted on the northern flank. The fault zone perfectly coincides with the $41^{\circ} \mathrm{N}$ lineament. Thickness change in Unit 1 (Mesozoic carbonates) and the relatively abrupt termination of Unit 2 (Miocene flysch terrains) across the fault would suggest a notable strike-slip component in addition to the main dip slip offset.

\section{Magnetic data analysis and interpretation}

After the already mentioned pre-processing stages, the anomaly field was corrected with respect to the regional field (IGRF 1995). The resulting map shows a very sharp low of about $800 \mathrm{nT}$ and a slightly pronounced high to the North, not exceeding $100 \mathrm{nT}$ (fig. 6). In this regard we recall that the shape of the magnetic anomalies is likely to reflect the direction of the 

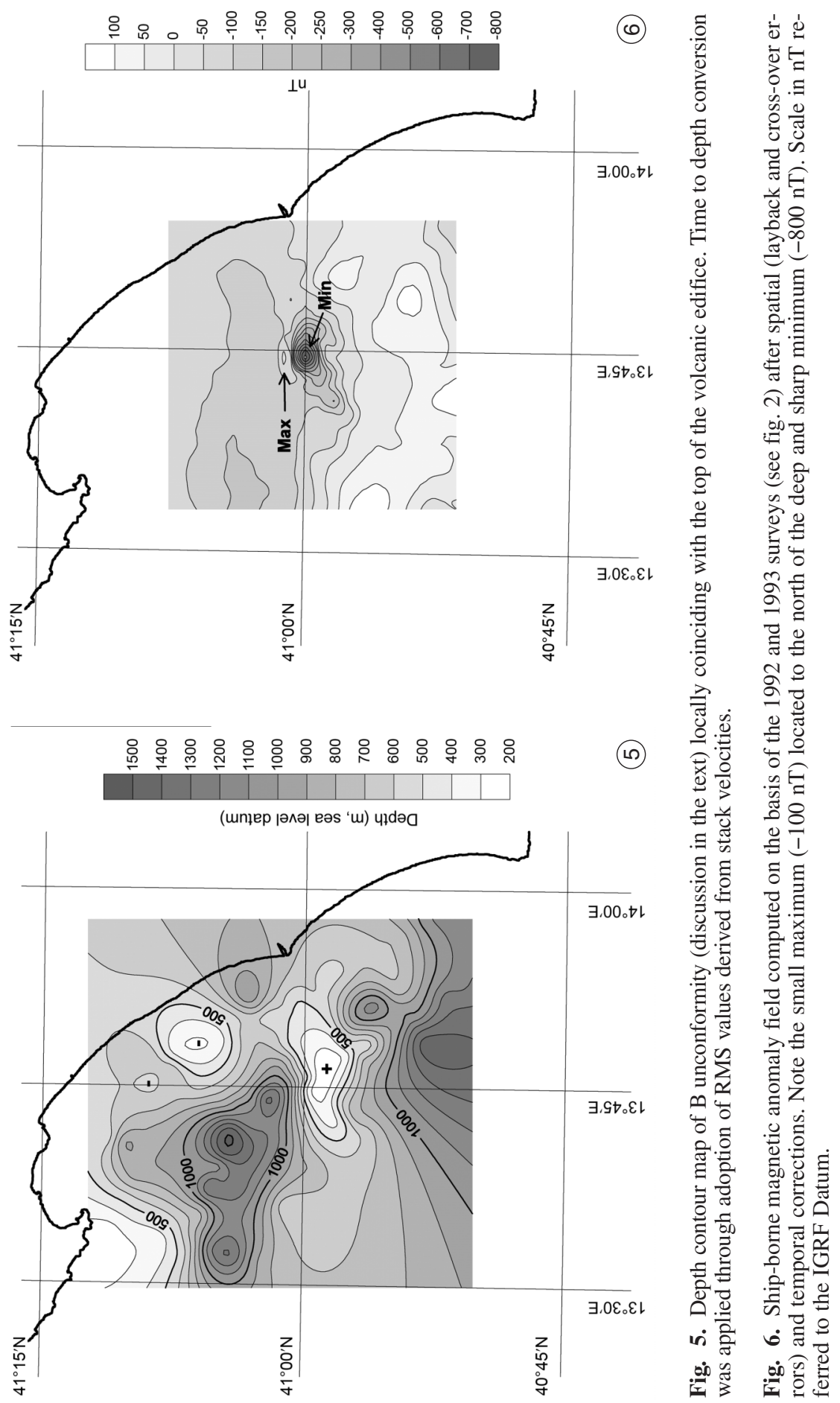

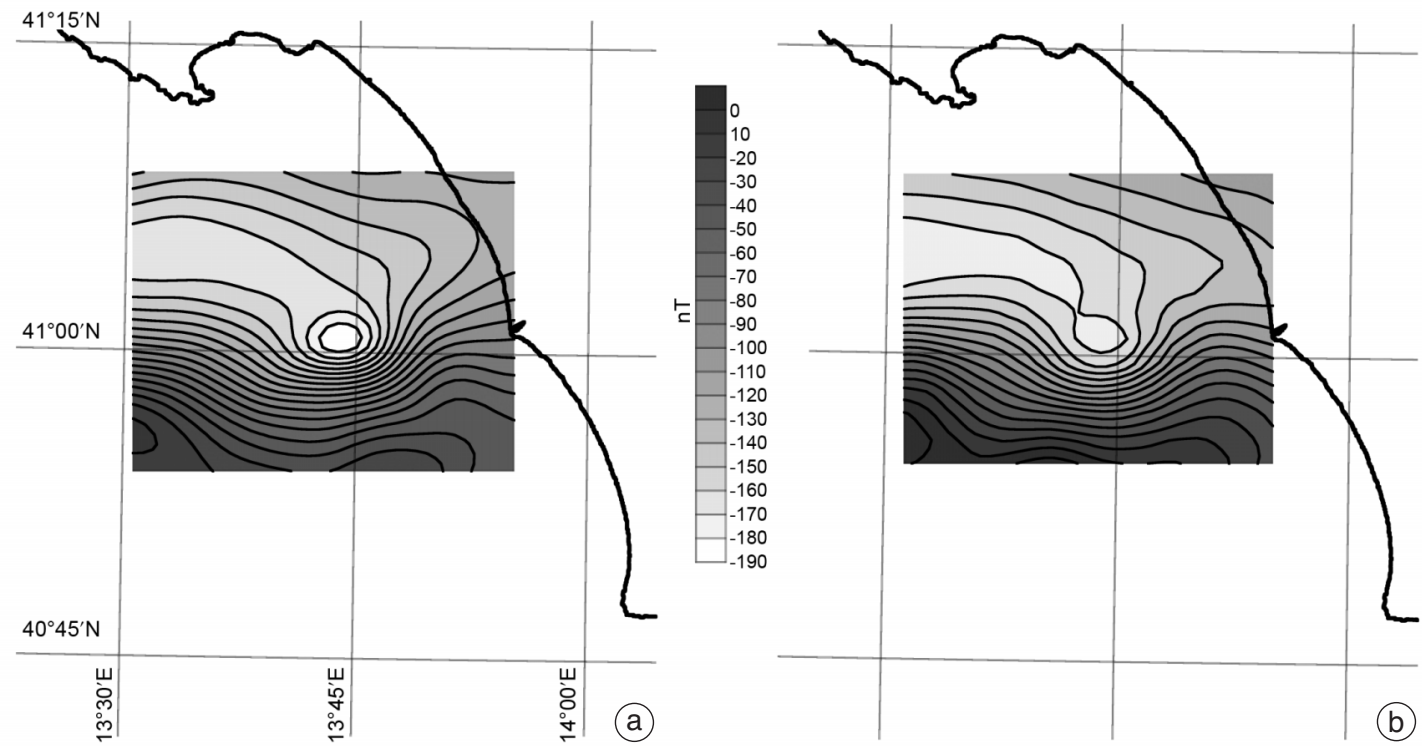

Fig. 7a,b. a) Upward continuation of the sea level magnetic anomaly field and comparison with b) aeromagnetic data acquired at the same altitude (2600 $\mathrm{m}$ a.s.l.). Scale in $\mathrm{nT}$.

Total Magnetisation Vector (TMV). TMV is in turn composed of induced and remanent magnetisation vectors. While the first follows the present-day direction of the inducing field, the second is along the past direction of the inducing field (at the time of cooling up to its own Curie point). If the magnetized body has moved since the time of emplacement, the remanent magnetization direction will also account for the displacement, since its direction is «frozen» within a reference system fixed to the body. Finally, it has to be noted that the anomaly source may have a very complex history, which results in a superposition of different magnetization vectors, each one related to different formation ages and dynamics. Although not all of the magnetic complexity may be reflected in the anomaly shape, the average direction of the total magnetization vector is nevertheless well detectable. Most of Tyrrhenian region anomalies, at sea and on land, have the same direction for the total and induced magnetization and, at the latitudes of our measurements, they have a dipolar shape, with a high-to-low axis northward oriented (e.g., among the most evident un- dersea: Marsili and Palinuro seamounts; among the subaerial volcanoes: Roccamonfina, Vesuvius, most Eolian Islands and Etna). On the contrary, the above described intense anomaly presents a high-to-low axis southward oriented like few other anomalies in the Tyrrhenian e.g., Vavilov seamount (Faggioni et al., 1995). To account for this, we have two possible explanations: a) that the source is a low susceptibility body hosted within highly magnetized rocks; b) that the source is a high susceptibility body, which presents a very high remanent magnetization along a direction opposite to that of the present inducing field. We will see that the second hypothesis is the most probable, and has interesting implications for the age of the source rocks and the nature of the related volcanism.

In order to test the data quality of the shipborne survey, we decided to compare it to a regional, airborne survey, acquired by the Agip Italian oil company on 1981 (see reference) at $2600 \mathrm{~m}$ a.s.l. To do this, our shipborne measurements were upward continued (e.g., Grant and West, 1965) from the sea-level to the airbornelevel. In order to compare them (fig. 7a,b) a con- 
stant level of $2880 \mathrm{nT}$ was subtracted from the airborne data, this value accounting for the different IGRF models applied to the two datasets. The very close similarity between the two anomaly fields (fig. 7a,b) supports the good quality of the marine dataset. Note that the marine survey low is slightly deeper than that from the airborne survey, due to its higher resolution (grid steps were $750 \mathrm{~m}$ and $2000 \mathrm{~m}$ respectively).

To obtain a more accurate description of the investigated area, the local effects were separated from that part of the field which is related to regional and deeper sources, i.e. the so-called regional field. It has been shown that this kind of separation may be efficiently performed through a technique based on the Discrete Wavelet Transform (Fedi and Quarta, 1998). The good performance of such separation is shown in fig. 8 where a poor correlation between local and regional fields is recognized.

After the subtraction of the regional effects, we tried to determine a reliable estimate of the direction of the total magnetization vector from the so-called distortion analysis (Fedi et al., 1994; Naidu and Matthew, 1998), which consists in an iterative processing of the dataset by a reduction

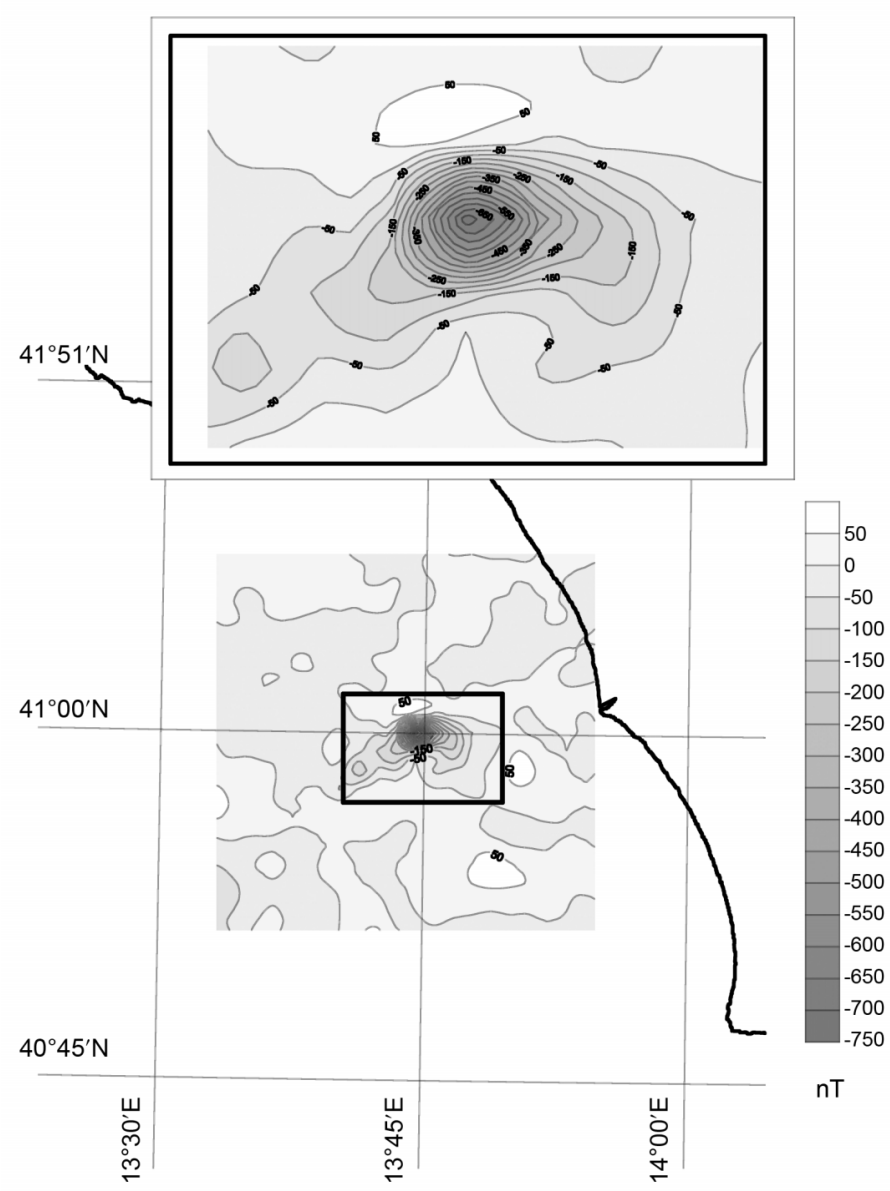

Fig. 8. De-trended ship-borne anomaly obtained with the application of the wavelet transform, separated from the long period gradient across $41^{\circ} \mathrm{N}$; compare to fig. 6 . The outlined field is zoomed in the upper box. 
to the pole operator. For sources having a positive magnetization contrast, the reduction to the pole transformation (Grant and West, 1965) has the effect of re-shape the anomaly as if it was produced at the magnetic pole, i.e. converting it to a single high shape. For a given anomaly, this is achieved using the most probable values of inclination (IT) and declination (DT) of the total mag- netisation vector. In our case, the iteration yielded $-25^{\circ}$ (counterclockwise from North i.e. $335^{\circ}$ ) for DT and $-70^{\circ}$ for IT. Such values were those adopted for the most effective reduction to the pole (fig. 9). The negative inclination suggests that the investigated source hosts a magnetization acquired during a reverse-polarity chron. Its value differs from the overall mean IT of the geo-

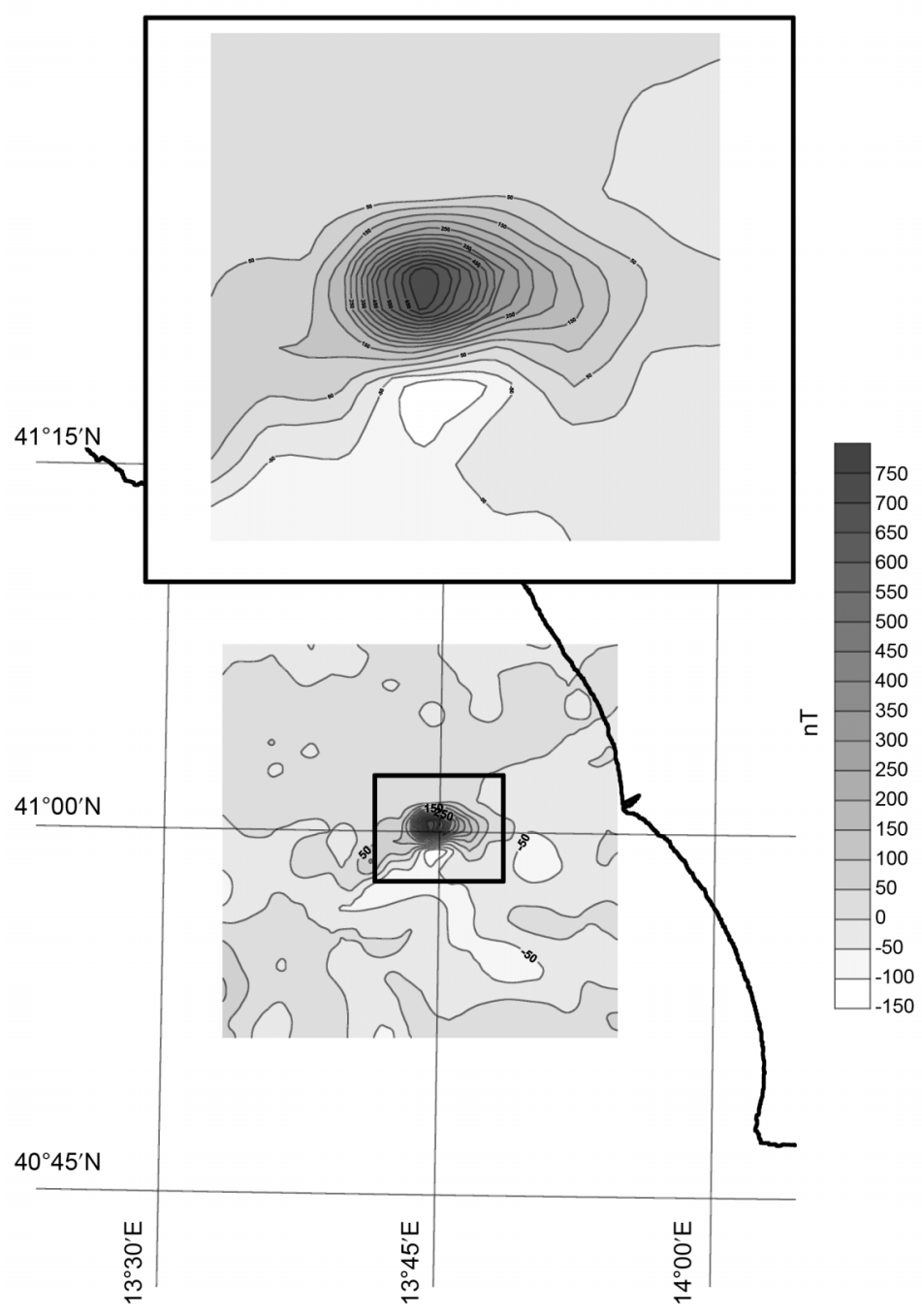

Fig. 9. The anomaly in fig. 8 has been reduced to the pole after a distortion analysis. This technique yielded $D=$ $=-25^{\circ}\left(335^{\circ}\right), I=-70^{\circ}$ for the direction of the total magnetization vector, suggesting that most part of the source was emplaced during a reverse-polarity magnetic interval. The outlined field is zoomed in the upper box. 


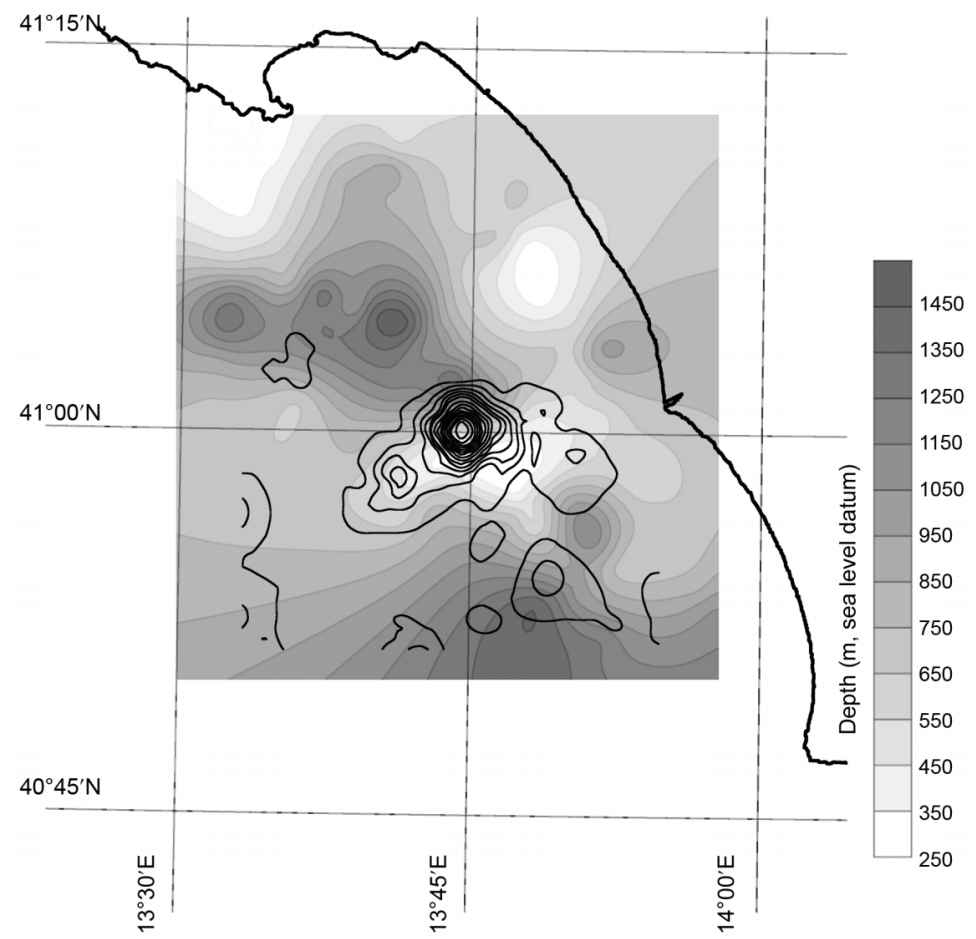

Fig. 10. Analytic Signal (2D) of the magnetic anomaly (thin line contour) and depth map of the top of the magnetic source (gray textures). The mismatch between the two maxima is in the order of $1.5 \mathrm{~km}$.

magnetic vector during reverse-polarity chrons for Southern Italy (for Upper Pliocene-Lower Pleistocene see Sagnotti and Meloni, 1993). However a value of $-70^{\circ}$ for inclination is within the range of the secular variations of the geomagnetic field when compared to the few available records derived from paleomagnetic (e.g., see Tiano et al., 2005) or archaeomagnetic (Evans and Hoye, 2005) studies over historic-prehistoric times in Southern Italy. Conversely detailed records of secular variations are still lacking for earlier intervals of the Pleistocene, in the region either during normal or reverse-polarity chrons.

As regards the spatial distribution of the magnetic sources, we tested different magnetic interpretation techniques: spectral methods to obtain an estimate of the average depth to source, the Analytic Signal to obtain an outline of the main source boundaries, and a non-linear $3 \mathrm{D}$ inverse technique to estimate the average 3D source space distribution.

Spector and Grant's (1970) well-known technique regards statistical ensembles of blocks of various sizes and magnetisation and is well suitable to study magnetic intrusions, or other sources, sketched as homogeneous bodies. The method is based on the fact that the logarithm of the radial power spectrum versus frequency is dominated by the factor $H(\rho, \bar{h}) \approx e^{-2 \bar{h} \rho}$ where $\bar{h}$ is the average depth to the top of a block ensemble of magnetic sources and $\rho$ stands for radial frequencies. We used this approach under the modification suggested by Fedi et al. (1997) in order to reduce the error of the depth estimation. The resulting average depth to source is $300 \mathrm{~m}$.

The horizontal extent of the magnetic source may be obtained with several techniques, one be- 


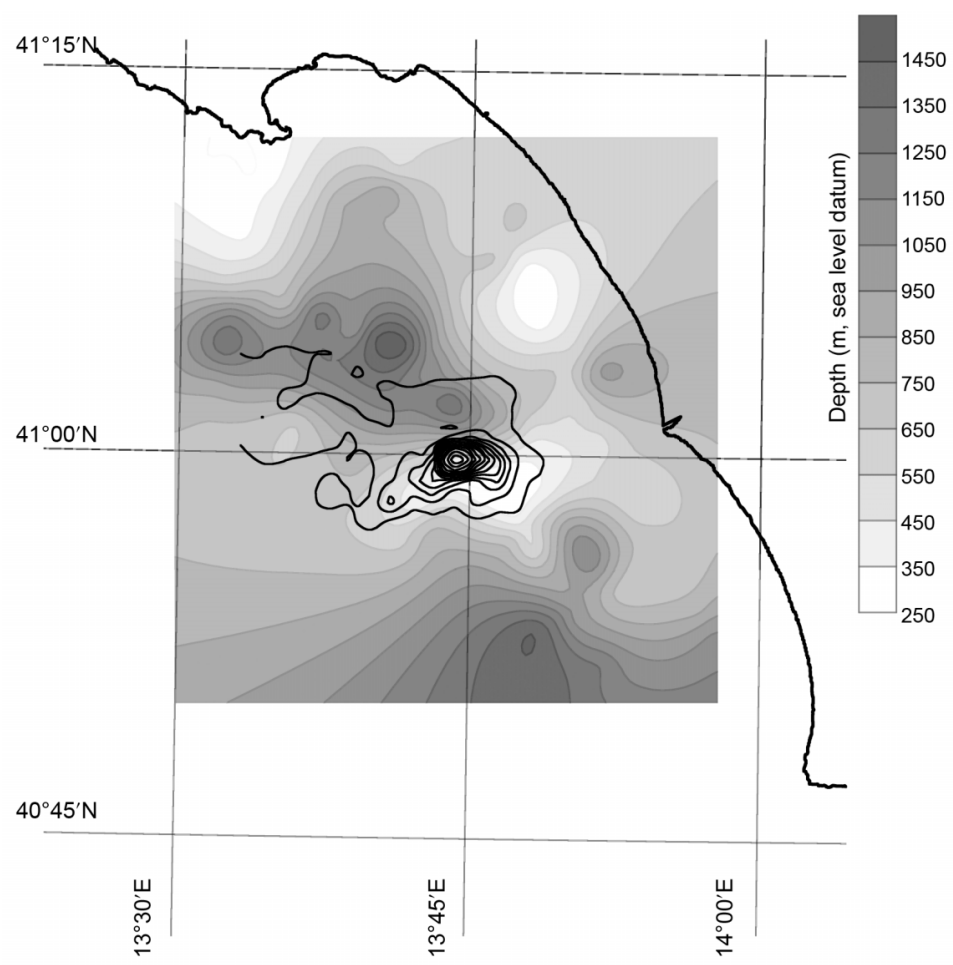

Fig. 11. 3D inversion based on the Fedi (1997) model of the magnetic anomaly (thin line contour) and depth map of the magnetic source (gray textures). The mismatch between the two maxima is in the order of $1 \mathrm{~km}$.

ing that based on the Analytic Signal which was chosen because almost independent on the magnetization vector direction. The Analytic Signal is a complex signal, whose real part is the horizontal derivative of the measured field, while its imaginary part is the vertical one. It may be shown that the maxima of its modulus are generally located at the source boundaries. In our case (fig. 10), the use of this method indicates an E-W elongated, $20 \times 5 \mathrm{~km}^{2}$ large source.

Finally, we turned to a 3D model of the magnetic source. It is well known that the complexity of the measured magnetic field over volcanic areas results from several factors, basically the interference of the effects from various sources, each characterised by different volumes, shapes, emplacement at different times and depths and susceptibility contrast, due to different chemical composition and lithology. Without definite con- straints, however, modelling should be based on few reasonable and simple assumptions. We used a non-linear 3D inverse technique due to Fedi (1997) which, assuming a homogeneous distribution of the magnetization contrast between source and embedding rocks, allows estimation of the 3D depth model of the source. The direction of the total and induced magnetisation vectors were given from the distortion analysis and from the 1995 IGRF model, respectively. We also assumed the maximum and minimum depths to the top of the source from the previously described spectral and seismic estimates. The resulting source model is shown in fig. 11. Even though more refined results could be obtained removing the assumption that the source magnetization is homogeneously distributed, the model shown gives a first-order definition and location of the magnetic sources. 


\section{Discussion and conclusions}

Unlike previous studies in this region, based solely on seismics (Aiello et al., 2000; Bruno et al., 2000) or very poorly constrained by magnetic data, our research integrates two independent datasets: seismics and ship-borne magnetics. The seismic interpretation and depth contour maps reveal a flat topped edifice, with gentle dipping flanks $\left(10^{\circ}\right.$ on the average) elevating 500-600 $\mathrm{m}$ from its surroundings. The edifice has an E-W trending, elliptical shape with major-minor axes $15 / 6 \mathrm{~km}$ respectively. Its flat top measures $2.5 \times 5 \mathrm{~km}^{2}$. Seismic evidence alone does not allow us to conclude that the unknown structure might correspond to carbonatic or volcanic rocks, since velocities and seismic facies are very similar for such kinds of rocks. On the other hand, the presence of an intense magnetic anomaly suggests the volcanic origin of most or of the entire edifice.

Seismic stratigraphy shows that the edifice is almost entirely sealed by a well identifiable horizon (C para-conformity) underlying the Volturno River delta. This evidence and the pinch out terminations of seismic reflectors on its flank might suggest that the edifice already existed prior to the emplacement of the Volturno River delta and its burial was coeval with the basin infill during high rates of tectonic subsidence. Its size and shape recall that of Roccamonfina volcano farther east and may suggest it was formerly entirely sub-aerial or in shallow waters. The age of the Volturno prograding wedge, based on its thickness and correlation to onshore well stratigraphy could be Middle Pleistocene to Present, i.e. 0.7-0 Ma (Brancaccio et al., 1991). We can therefore tentatively assume that the volcano, once sub-aerial, or in very shallow waters, has undergone a tectonic subsidence that lowered its summit from a hypothetical height of 500-600 m above sea level to its present elevation at $-250 \mathrm{~m}$ b.s.l. This implies rates of $1 \mathrm{~mm} / \mathrm{yr}$ for the total subsidence (i.e. tectonic and sedimentary) during Middle Pleistocene to Present that are consistent with values calculated from well stratigraphy onshore (Brancaccio et al., 1991) or along this Eastern Tyrrhenian margin (Argnani and Savelli, 1999).

At the same time we remark that the shipborne magnetic anomaly corresponding to our structure shows a $-800 \mathrm{nT}$ sharp low coupled with a broad $100 \mathrm{nT}$ high with the high-to-low
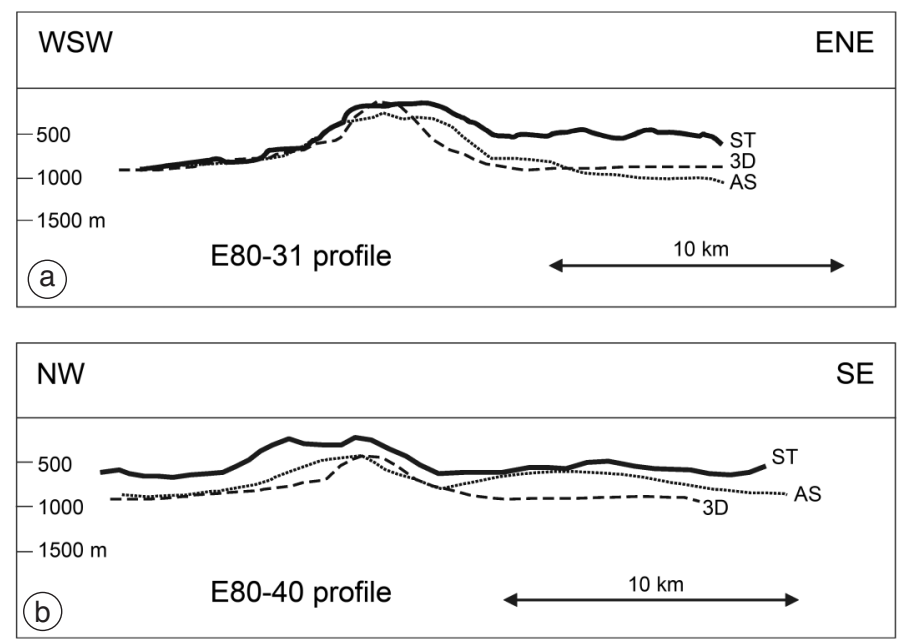

Fig. 12a,b. 2D comparison between seismic derived topography (ST), Analytic Signal (AS) and Fedi (1997) 3D inversion (3D) along the a) E80-31 and b) E80-40 seismic lines of figs. 3 and 4 located in fig. 2. 
axis pointing to the south. This evidence indicates a magnetic inversion, like only few other volcanoes of the Tyrrhenian region (Faggioni et al., 1995). This inversion cannot be easily observed on aeromagnetic field (Agip, 1981), due to the loss of resolution. Declination and inclination of the total magnetization vector evaluated with a distortion analysis yielded $-25^{\circ}$ $\left(335^{\circ}\right)$ and $-70^{\circ}$, respectively. While the inclination is consistent with a reverse-polarity chron and its value falls within the range of secular variations of the geomagnetic field (well known from literature only for pre-historic and historical times) such correlation is not supported by the value of the declination. However an emplacement which occurred during the last Pleistocene reverse-polarity chron [Matuyama 0.78-1.78 Ma according to Cande and Kent GPTS (Cande and Kent, 1995)] is fully consistent with seismic stratigraphy assuming that most of the volcanic (igneous) material was ejected during this period. Seismic data suggest in fact that the volcanic edifice was basically emplaced prior to Middle-Late Pleistocene i.e. prior to about $0.7 \mathrm{Ma}$.

As regards the geometric definition of this source, the magnetic model indicates a relatively wide $\left(20 \times 5 \mathrm{~km}^{2}\right)$ structure characterised by an eccentric spike (around $5 \times 5 \mathrm{~km}^{2}$ ) over its northern flank. The spike might be interpreted as a magmatic intrusion inside a pyroclastic edifice (visible 3D depth magnetic source model, fig. 11). The very good correspondence between Seismic Topography (ST) and boundary analysis (AS: Analytic Signal) shows that the entire buried structure corresponds to a magnetic source, i.e. may be interpreted as an E-W elongated volcanic edifice (fig. 12a,b).

The occurrence of a subaerial, elongated volcanic edifice presenting internal magnetic (i.e. geological) heterogeneities provides some analogies to what was observed at adjacent outcropping or buried volcanoes, all located along the $41^{\circ} \mathrm{N}$ lineament and with comparable age. As a matter of fact, sub-aerial, Middle Pleistocene volcanism is observed at Zannone Island, i.e. to the West of the lineament, in the form of trachytic lava domes and pyroclasts (De Rita et al., 1986). On the other hand, in the subsurface of the Volturno plain, to the East of the $41^{\circ}$ lineament, the presence of a former sub-aerial edifice, named the «Parete» volcano with an inferred Middle Pleistocene age, could be suggested by the huge thickness of volcanic lavas encountered by deep wells (Ortolani and Aprile, 1978). Between Zannone Island and the Parete volcano, i.e. along the entire $100 \mathrm{~km}$ long $41^{\circ} \mathrm{N}$ magnetic and tectonic boundary, seismic and bathymetric evidence seems to indicate other volcanic/igneous bodies. One of these bodies is located at $41^{\circ} 05^{\prime} \mathrm{N}, 13^{\circ} 30^{\prime} \mathrm{E}$, in a high gradient zone of the aeromagnetic field (de Alteriis, unpublished data).

\section{Acknowledgements}

We wish to thank Eni Agip-division, former Agip Exploration and Production, Milan for having permitted the publication the two seismic profiles shown. A. Incoronato provided useful suggestions and comments. O. Faggioni and F. Speranza are kindly acknowledged for having improved the quality of the paper during the reviewing phase.

\section{REFERENCES}

AgIP (1981): Carta Magnetica d'Italia-Anomalie del Campo Magnetico Residuo, Scala 1:500000 (S. Donato Milanese (MI)).

Aiello, G., E. Marsella and M. SACChi (2000): Quaternary structural evolution of Terracina and Gaeta basins (Eastern Tyrrhenian margin, Italy), Rend. Fis. Acc. Lincei, 11, 41-58.

Argnani, A. and C. Savelli (1999): Cenozoic volcanism and tectonics in the Southern Tyrrhenian Sea: spacetime distribution and geodynamic significance, J. Geodyn., 27, 409-432.

Bartole, R., D. Savelli, M. Tramontana and F.C. Wezel (1984): Structural and sedimentary features in the tyrrhenian margin off Campania, Southern Italy, Mar. Geol., 55, 163-180.

Brancaccio, L., A. Cinque, P. Romano, C. Rosskopf, F. Russo, N. Santangelo and A. SAnto (1991): Geomorphology and neotectonic evolution of a sector of the Tyrrhenian flank of the Southern Appennines, Zeitschrift Geomorph., 82, 47-58.

Bruno, P.P., V. Di Fiore and G. Ventura (2000): Seismic study of the '41st parallel' Fault System offshore the Campanian-Latial continental margin, Italy, Tectonophysics, 324, 37-55.

CANDE, S.C. and D.V. KENT (1995): Revised calibration of the geomagnetic polarity timescale for the Late Cretaceous and Cenozoic, J. Geophys. Res., 100, 6093-6095. 
CAPAldi, G., L. CivetTA and P.Y. Gillot (1985): Geochronology of Plio-Pleistocene volcanic rocks from Southern Italy, Rend. Soc. Ital. Mineral. Petrol., 40, 25-44.

De Rita, D., R. Funiciello, D. Pantosti, F. Salvini, A. Sposato and M. Velonì (1986): Geological and structural characteristics of the Pontine Islands (Italy) and implications with the evolution of the Tyrrhenian margin, Mem. Soc. Geol. Ital., 36, 55-67.

EvANS, M.E. and G.S. HoYe (2005): Archaeomagnetic results from Southern Italy and their bearing on geomagnetic secular variations, Phys. Earth Planet. Int., 151, 155-162.

Faggioni, O., E. Pinna, C. SAVelli and A.A. Schreider (1995): Geomagnetism and age study of Tyrrhenian seamounts, Geophys. J. Int., 123, 915-930.

FEDI, M. (1997): Estimation of density, magnetization, and depth to source: a non-linear and noniterative $3 \mathrm{D}$ potential-field method, Geophysics, 62 (3), 814-830.

FEDI, M. and G. Florio (2001): Potential fields source boundaries detection by an enhanced horizontal derivative, Geophys. Prospecting, 49 (1), 13-25.

FEDI, M. and T. QuARTA (1998): Wavelet analysis for the regional-residual and local separation of potential field anomalies, Geophys. Prospecting, 46, 507-525.

FEDI, M., G. Florio and A. RAPOLla (1994): A method to estimate the total magnetisation direction from a distortion analysis of magnetic anomalies, Geophys. Prospecting, 42, 261-274.

Fedi, M., T. Quarta and A. De Santis (1997): Inherent power-law behavior of magnetic field power spectra from a Spector and Grant ensemble, Geophysics, 62 (4), 1143-1150.

GRANT, F.S. and G.F. West (1965): Interpretation Theory in Applied Geophysics (McGraw-Hill Book Company, New York), pp. 584.

Hsu, S., J.C. Sibuet and C. Shyu (1996): High-resolution detection of geologic boundaries from potential field anomalies: an enhanced Analytic Signal technique, Geophysics, 61, 373-386.

IPPOlito, F., F. ORTOlani and M. Russo (1973): Struttura marginale tirrenica dell'Appennino Campano: reinterpretazione di dati di antiche ricerche di idrocarburi, Mem. Soc. Geol. Ital., 12, 227-250.
Marani, M. and F. GAMBeri (2004): Structural framework of the Tyrrhenian Sea unveiled by seafloor morphology, Memorie Descrittive della Carta Geologica d'Italia, XLIV, 97-108.

Mariani, M. and R. Prato (1988): I bacini neogenici costieri del margine tirrenico: approccio sismico stratigrafico, Mem. Soc. Geol. Ital., 41, 519-531.

NAIDU, P.S. and M.P. MATTHEw (1998): Analysis of Geophysical Potential Fields: a Digital Processing Approach, Advances in Exploration Geophysics Ser. 5 (Elsevier), pp. 310.

Ortolani, F. and F. ApriLE (1978): Nuovi dati sulla struttura profonda della piana campana a sud est del fiume Volturno, Boll. Soc. Geol. Ital., 97, 591-608.

Roest, W.R., J. VERHOEF and M. PILKINTON (1992): 3D Analytic Signal, Geophysics, 57 (1), 116-125.

Sagnotti, L. and A. Meloni (1993): Pleistocene rotations and strain in Southern Italy: the example of the Sant'Arcangelo Basin, Ann. Geofis., XXXVI (2), 83-95.

SAVELli, D. and F.C. Wezel (1979): Morfologia e stile tettonico del Bacino Tirrenico, in Atti Conv. Sc. Naz., P.F. 'Oceanografia e Fondi Marini', Roma, Italy, 2, 729-738.

SELli, R. (1981): Thoughts on the geology of the Mediterranean region, in Sedimentary Basins of Mediterranean Margins, edited by F.C. WEZEL (Tecnoprint, Bologna), 489-501.

SPECTOR, A. and F.S. GRANT (1970): Statistical models for interpreting aeromagnetic data, Geophysics, 35, 293302.

Tiano, P., A. Incoronato and D.H. TARLing (2005): Paleomagnetic study on Vesuvius lava flows, Geophys. J. Int., 163, 518-526.

Trincardi, F. and N. Zitellini (1987): The rifting of the Tyrrhenian Basin, Geo-Mar. Lett., 7, 1-6.

WEZEL, F.C. (1985): Structural features and basin tectonics of the Tyrrhenian Sea, in Geological Evolution of the Mediterranean Basin, edited by D.J. STANLEY and F.C. WEZEL (J. Wiley, New York), 153-194.

(received October 19, 2005; accepted September 20, 2006) 